Nazarenko I. L., Associate Professor Ukrainian State University of Railway Transport

Kharkiv, Ukraine

DOI: https://doi.org/10.30525/978-9934-26-018-6-12

\title{
ECONOMIC SECURITY OF SMALL FAMILY BUSINESS AFFECTED BY PANDEMIC: IDENTIFYING NEW THREATS
}

Family business is known to be a pivot of world's economy, its impact on the global economy is tremendous. Percentage of family business contribution to national GDP varies from $27 \%$ in Bahrain to 90\% in United Mexican States.

Nowadays, the COVID-19 pandemic is severely testing the attributes that give family businesses a competitive edge. The ability to survive and prepare for the "new normal" is critical to the future of any family, business and all the people who rely on it [1]. The coronavirus pandemic is affecting small businesses in a variety of ways. From loss of business to remote work, things are changing fast during the COVID-19 outbreak and businesses are being forced to adapt.

Additionally, a crisis typically hits the owners of family firms twice, i.e. once as private citizens and in a second round as business owners [2].

There is a lot of evidence about small businesses in the counties of EU, the USA and all around the globe suffering from quarantine, decreasing of demand, losses and bankruptcies (for instance, in [3; 4]). As for Ukraine, there is neither any accurate statistical data about family business' percentage in GDP, nor any data about their exact number, but we assumed in $[5 ; 6]$ that majority of medium-size, small and (as a part of small ones) microenterprises are family-owned 
(especially those which are registered as individual entrepreneurs). We developed some strategies of small family businesses survival during and after quarantine in [7].

However, according to aforementioned, there is a great necessity of systematic approach to tackling new challenges small businesses face with. It should be based on ensuring economic security. Which is why the purpose of this study is identifying main threats to the components of economic security of small family business in accordance with its specifics.

The object of the study is given in the fig. 1 and lays at the intersection of the three spheres - Family Business with its specifics, Small Business with its specifics and Economic security.

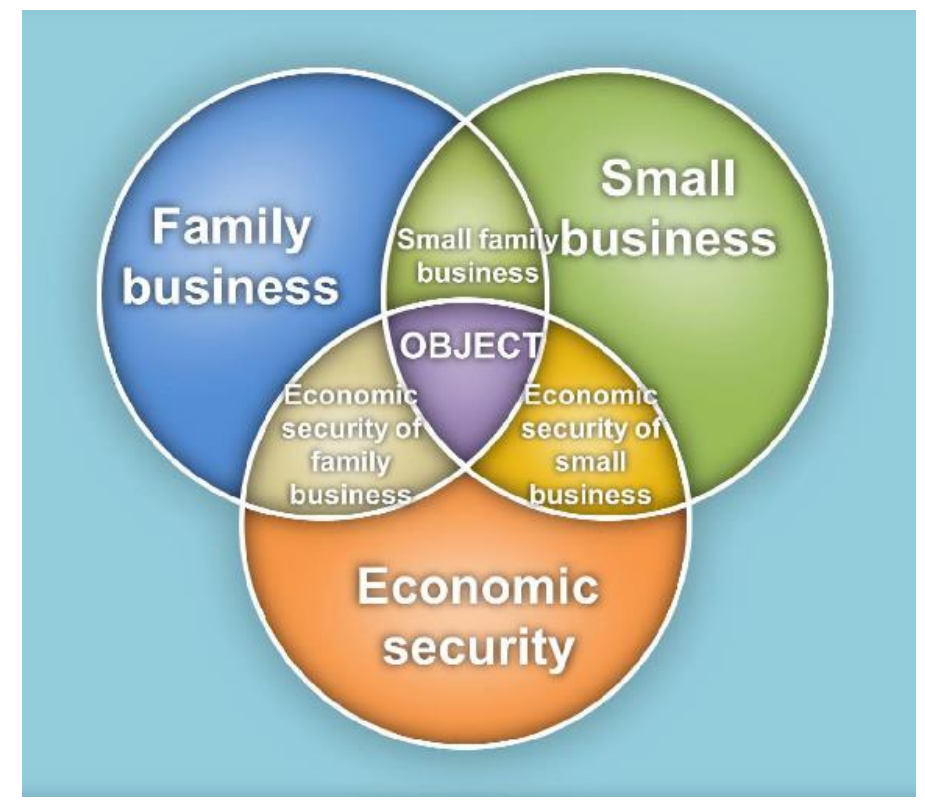

\section{Figure 1. Object of economic security of a small family business}

Source: developed by the author

Economic security of an enterprise is a state of its protection from external and internal threats, as well as the ability to quickly adapt to changes in the external environment that are not threatening [8]. 
The main principles of family business according to D. KenyonRouvinez [9] are: strength in unity, ability to handle conflicts, fairness, social engagement, strong values, pride and mutual support. They might well help any family business to tackle various challenges.

According to Ukrainian Family Business survey, conducted in 2019 by Lviv Business School of Ukrainian Catholic University and Sociological agency Fama [10], there are several traits which help family businesses to survive.

The first is viability, which affects how quickly a business can return to its equilibrium state after extreme events. And family businesses, even if they are very young and have not yet experienced a business crisis, have an advantage. Because, most likely, they faced a crisis in family life: a misunderstanding, a divorce, and the loss of loved ones. And this gave them vitality which can be applied now.

Another advantage of family firms is their entrepreneurship. It is in their DNA, because all family firms come from the founding parents, and the history of the their foundation and development is what children grow up with. And family firms are looking not only for financial benefits, but also for social dividends, a positive impact on the environment in which they work. In fact, the crisis shows the entrepreneurship of family firms: they are able to make quick decisions, adapt, even change the sphere of their activities.

Family firms are based on trust and unity. 77\% of respondents in the study [10] mentioned this as an advantage of family business. And these are the values which are especially helpful in times of crisis.

Family business is often much more than just business. This is, above all, philosophy and a set of values. Family business owners plan their future for many years to come. They are not focused on the today's result, but on long-term strategic planning. It is a "long game" and a high level of responsibility [11].

We identified the main threats to tconomic security of Small Family Businesses caused by pandemic (table 1). Names of components are borrowed from [12] and adapted to small business. 
According to [12], economic security components of a firm are types of activity for its ensuring.

To sum up, the main threats to economic security of Small Family Business caused by pandemic are identified and classified in this study by components of economic security. We are sure that the specificity of small business (adaptability to the environment, low operating costs, relatively small savings that make them dependent on state aid in force majeure circumstances, etc.) modifies or even aggravates threats to their economic security, but the listed above traits of family business influence ways of ensuring economic security and increase the chances of survival against all odds.

Table 1

\section{Main threats to economic security of Small Family Businesses caused by pandemic}

\begin{tabular}{|c|c|}
\hline $\begin{array}{c}\text { Components } \\
\text { of Economic Security } \\
\text { of small firms }\end{array}$ & $\begin{array}{l}\text { Main specific threats caused } \\
\text { by pandemic }\end{array}$ \\
\hline 1 & 2 \\
\hline $\begin{array}{l}\text { 1. Financial component } \\
\text { (security of financial and } \\
\text { economic activities, high } \\
\text { levels of profitability, } \\
\text { liquidity, financial } \\
\text { independence, etc.) }\end{array}$ & $\begin{array}{l}\text { 1. Dramatic decline in effective demand } \\
\text { and, consequently, in revenue and profit. } \\
\text { 2. Lack of financial safety cushion, } \\
\text { inability to outlast the temporary lockdown. }\end{array}$ \\
\hline $\begin{array}{l}\text { 2. Intellectual and personnel } \\
\text { component (good } \\
\text { performance of staff, } \\
\text { preservation and } \\
\text { development of the } \\
\text { intellectual potential) }\end{array}$ & $\begin{array}{l}\text { 1. Possibility of losing valuable } \\
\text { employees due to the pandemic. } \\
\text { 2. Psycho-social problems, overwork and } \\
\text { stress, task complexity in remote work, etc., } \\
\text { decreased performance. } \\
\text { 3. Lack of qualified staff and skills to } \\
\text { develop a strategy of survival, } \\
\text { diversification, etc. }\end{array}$ \\
\hline
\end{tabular}


Table 1 (continued)

\begin{tabular}{|c|c|}
\hline 1 & 2 \\
\hline $\begin{array}{c}\text { 3. Technical and } \\
\text { technological component } \\
\text { (relatively new equipment, } \\
\text { technologies meeting world } \\
\text { standards) }\end{array}$ & $\begin{array}{c}\text { 1. Lack of equipment and technology for } \\
\text { distance working. } \\
\text { 2. Firm's existing equipment may be } \\
\text { outdated for new working conditions. }\end{array}$ \\
\hline $\begin{array}{c}\text { 4. Legal component } \\
\text { (compliance with laws and } \\
\text { regulations) }\end{array}$ & $\begin{array}{c}\text { 1. Fines imposed for violation of } \\
\text { regulations (work during a lockdown). } \\
\text { 2. The need to adapt to new conditions } \\
\text { and instructions from the state. }\end{array}$ \\
\hline $\begin{array}{c}\text { 5. Informational component } \\
\text { protection of the firm's data } \\
\text { and preservation of trade } \\
\text { secrets; collection and } \\
\text { analysis of all information } \\
\text { related to firm's activities) }\end{array}$ & $\begin{array}{c}\text { 1. Interception of firm's reports, leakage } \\
\text { of valuable data. }\end{array}$ \\
\hline $\begin{array}{c}\text { 6. Power component } \\
\text { (physical security of } \\
\text { employees and preservation } \\
\text { of enterprise property) }\end{array}$ & Threat of being looted by hooligans and \\
\hline $\begin{array}{c}\text { 7. Ecological component } \\
\text { (optimization of costs for } \\
\text { ensuring compliance with } \\
\text { environmental standards) }\end{array}$ & No new threats. \\
\hline
\end{tabular}

The results obtained in the study can be used in further research in this realm, for developing the ways of ensuring economic security of small family businesses.

\section{References:}

1. Family Businesses and COVID-19: Our support and recommendations (2020). Avaliable at: https://www.pwc.com/gx/en/services/family-business/assets/family-businesses-and-covid-19.pdf.

2. Sascha Kraus, Thomas Clauss, Matthias Breier, Johanna Gast, Alessandro Zardini, Victor Tiberius (2020) The economics of COVID-19: Initial empirical evidence on how family firms in five European countries cope with the corona crisis. International Journal of Entrepreneurial Behavior \& Research, pp. 1-36. 
3. COVID-19: The Great Lockdown and its Impact on Small Business (2020). Available at: https://www.intracen.org/publication/COVID-19-The-Great-Lockdownand-its-Impact-on-Small-Business---SMECO-2020-Executive-Summary-en.

4. Kim O.S., Parker J.A., Schoar A. (2020) Revenue Collapses and the Consumption of Small Business Owners in the Early Stages of the COVID-19 Pandemic. Available at: https://www.nber.org/papers/w28151.

5. Nazarenko I.L., Sukhorukova D.O. (2019) Implementation of Value Based Management in Small Family Retail Business. Bulletin of Economics of Transport and Industry, vol. 68, pp. 51-59.

6. Nazarenko I.L., Shepel V.M. (2020) Value Based Management in Small Family Retail Business affected by quarantine. Bulletin of Economics of Transport and Industry, vol. 70-71, pp. 5 - 11 .

7. Nazarenko I.L. (2020) Strategies of small family businesses survival during and after quarantine. Bulletin of Economics of Transport and Industry, vol. 69, pp. $92-100$.

8. Kovalov D.I., Plietnykova I.L. (Nazarenko I.L.) (2001) Kil'kisna otsinka rivnya ekonomichnoyi bezpeky pidpryyemstva [Quantitative assessment of the level of economic security of an enterprise]. Economics of Ukraine, vol. 4, pp. 35-40. (in Ukrainian)

9. Kenyon-Rouvinez D. (2017) Secrets of success in long-lasting family firms. IMD - International Institute for Management Development. No. 2-17. Available at: https://www.imd.org/research-knowledge/articles/secrets-of-success-in-long-lastingfamily-firms.

10. Simeynyy biznes v Ukrayini: osoblyvosti zapochatkuvannya, vedennya ta peredachi nastupnym pokolinnyam [Family business in Ukraine: features of starting, running and passing on to the next generation] (2019). Available at: https://lvbs.com.ua/wp-content/uploads/2019/12/simeinyi-biznes.pdf.

11. Voronovska R.(2020). Simeynyy biznes: choho varto povchytysya u kryzovi chasy? [Family business: what to learn in times of crisis?]. Available at: https://blog.liga.net/user/rvoronovska/article/37058.

12. Osnovyi ekonomicheskoy bezopasnosti (Gosudarstvo, region, predpriyatie, lichnost). (1997) [Fundamentals of Economic Security (State, Region, Enterprise, Personality)]. Edited by E.A. Oleinikov Moscow: ZAO 'Biznes-shkola "Intel-Sintez". (in Russian). 